\title{
Quantification of Live 'Candidatus Liberibacter asiaticus' Populations Using Real-Time PCR and Propidium Monoazide
}

H. Hu, M. J. Davis, and R. H. Brlansky, University of Florida, Institute of Food and Agriculture Sciences, Citrus Research and Education Center, Lake Alfred 33850

\begin{abstract}
Hu, H., Davis, M. J., and Brlansky, R. H. 2013. Quantification of live 'Candidatus Liberibacter asiaticus' populations using real-time PCR and propidium monoazide. Plant Dis. 97:1158-1167.

Huanglongbing (HLB) is a devastating citrus disease. It is associated with a phloem-restricted bacterium, 'Candidatus Liberibacter asiaticus', and primarily transmitted by Asian citrus psyllid in Florida. Because Liberibacter cannot be cultured, early diagnosis of HLB relies on DNA-based polymerase chain reaction (PCR), including real-time quantitative (q)PCR. Although estimating genomes from live bacteria (GLB) is critical for HLB research, PCR does not distinguish between live and dead cells and, thus, does not estimate GLB in hosts. Propidium monoazide (PMA), a novel DNA-binding dye, has been successfully used on many bacterial pathogens to effectively remove DNA from dead cells but there is no report of its use on uncultured bacteria.

In this study, PMA-qPCR protocols were first optimized to work with plant and psyllid samples, respectively. Both TissueLyser treatment and plant tissue were demonstrated to have an insignificant impact on the GLB detected by PMA-qPCR. Finally, a standard curve for GLB determination was successfully established between PMA-qPCR results and microscopic counts and then applied in two studies with different greenhouse plant samples. This rapid qPCR method provides a more accurate way to determine GLB in HLB hosts which, in turn, should benefit disease epidemiology studies and serve as a crucial component in HLB management.
\end{abstract}

Citrus huanglongbing (HLB), also called citrus greening, is one of the most devastating citrus diseases worldwide. It causes severe crop losses and threatens the citrus industry on multiple continents $(3,8)$. The disease is associated with a phloem-restricted, gramnegative bacterium which belongs to the 'Candidatus' genus Liberibacter in the $\alpha$ subdivision of the Proteobacteria (16). Three Liberibacter spp. are known: 'Candidatus Liberibacter asiaticus' in Asia and the America continents $(3,13,36)$; ' $\mathrm{Ca}$. L. africanus' in Africa (8,12,33); and ' $\mathrm{Ca}$. L. americanus' in Brazil only (37). The bacterium has not been cultured yet, nor have Koch's postulates been satisfied. ' $\mathrm{Ca}$. L. asiaticus' is the most prevalent HLB-associated Liberibacter sp. in the world (3), and also is the only one found in the United States since the discovery of HLB in Florida in 2005 (13). In addition to graft-transmission, ' $\mathrm{Ca}$. L. asiaticus' is naturally vectored and transmitted by the Asian citrus psyllid (ACP) (Diaphorina citri) in the field $(3,8,14)$, and it is widely accepted that HLB-associated Liberibacter can multiply and accumulate to a relatively high population inside the insect host $(9,14)$.

Due to the inability to isolate Liberibacter on growth medium and the confusion of HLB symptoms with those of disorders such as $\mathrm{Zn}^{2+}$ deficiency, HLB diagnosis usually relies on DNA-based methods, most commonly polymerase chain reaction (PCR) assays (3). The disease can be diagnosed with electron microscopy but such assays are time consuming and require appropriate sample preparation because the bacteria is known to be unevenly distributed in planta $(3,8,35)$. Reliable serological assays have not been completely developed, largely due to the difficulties in raising specific antibodies to an uncultured organism and the variation of antigen traits of the target bacteria (3). Several pairs of conventional PCR primers have been developed that amplify 16S rDNA and ribosomal protein gene fragments, and these assays are now routinely used for HLB diagnosis $(15,17,36)$. However, the ampli-

Corresponding author: R. H. Brlansky, E-mail: rhby@ufl.edu

Accepted for publication 9 March 2013.

http://dx.doi.org/10.1094/PDIS-09-12-0880-RE

(c) 2013 The American Phytopathological Society cons in these conventional PCR tests are quite long and do not lend themselves to stable, sensitive PCR reactions, which is quite a disadvantage because early diagnosis aids in HLB control. In addition, a restriction fragment length polymorphism test needs to be performed to differentiate ' $\mathrm{Ca}$. Liberibacter spp.' Therefore, realtime fluorescent PCR (qPCR) was quickly adopted to provide better sensitivity, specificity, and speed for HLB diagnostic purposes $(21,22,41)$. Because it is quantitative $(1,2)$, qPCR is often used in various HLB research programs to investigate disease epidemiology and progress $(35,39,41)$.

Quantification of the number of pathogen cells in a host aids in investigation of virulence mechanisms and disease management. However, DNA-based methods, including qPCR, have the limitation that they cannot differentiate between live and dead cells, although only live cells are of interest for most research purposes. Because bacterial genomic DNA can persist up to 3 weeks after cell death $(18,25)$, DNA-based diagnostics tend to overestimate live populations. In the case of HLB, it has been speculated that Liberibacter is present in citrus as much as $10^{7}$ to $10^{8}$ cells/g of tissue based on qPCR data $(21,39,41)$. However, the bacterial population observed with microscopy is usually lower by orders of magnitude (38). Considering that direct counting using microscopes only focuses on bacteria with cell structure while DNAbased assays detect all DNA in the sample, the discrepancy between data from the two types of methods is understandable. In order to minimize the difference and focus on the genomes from live bacteria, an effective way to remove background DNA (including naked DNA or DNA from dead cells) is needed.

Ethidium monoazide (EMA) is a DNA-intercalating dye with an azide group that binds to DNA upon exposure to bright light (maximum absorbance at $460 \mathrm{~nm}$ ) and, thus, renders the DNA insoluble during DNA extraction and undetectable by PCR (27). EMA was used in combination with qPCR to remove the DNA from dead cells and, thus, only detect the DNA extracted from live cells in the consequent qPCR $(27,34,39,40)$. However, poor selectivity of EMA (i.e., EMA can also penetrate into live cells during the pretreatment step and, thus, causes DNA loss from live cells) rendered the chemical problematic when applied to various bacteria $(4,10,19,29)$. For example, in a study of Escherichia coli O157:H7, although EMA successfully removed all genomic DNA 
from dead cells, the treatment also resulted in a loss of about $60 \%$ of the genomic DNA of live cells harvested from the log phase (27). In order to overcome this limitation, a novel chemical, propidium monoazide (PMA), was tested (29). PMA is identical to propidium iodide, a commonly used membrane-impermeant dye in commercial live or dead bacteria staining kits, except with an additional azide group. It binds with DNA molecules in the same way as EMA and, thus, effectively removes background DNA. However, PMA is highly selective in penetrating only into dead cells with compromised cell membranes but not live cells with intact cell membranes. This is probably due to two positive charges on the PMA molecule compared with a single positive charge on EMA (29). This feature of PMA was confirmed in a wide range of gram-negative and -positive bacteria (29), and, thus, PMA has replaced EMA for qPCR (i.e., qPCR with PMA pretreatment, termed "PMA-qPCR") in quantifying genomes from live bacteria (GLB) $(5,28,30,32)$.

Although PMA-qPCR has been used to quantify populations of live bacteria $(20,23,31,42)$, there is, thus far, no report of PMAqPCR application on uncultured bacteria such as the HLB-associated Liberibacter. In this study, we redesigned and optimized protocols of PMA-qPCR which were originally designed to work with pure bacterial cultures, and compared the difference between PMA and EMA treatments when working with ' $\mathrm{Ca}$. L. asiaticus'. After the insignificant impact of the plant tissue on PMA-qPCR was demonstrated, a standard curve between qPCR quantification results and microscopic counting was established. Finally, PMAqPCR methodology and the standard curve were used to quantify the GLB in greenhouse samples. The rapid and quantitative PCR methodology developed in our study should provide a more accurate way to determine the live ' $C a$. L. asiaticus' population in plants and psyllids which, in turn, should benefit research in disease epidemiology, plant-microbe, and insect-microbe interactions, thereby serving as a crucial component in HLB management.

\section{Materials and Methods}

Plants and psyllid materials. ' $C a$. L. asiaticus'-infected citrus species and other alternative host plants were sampled from greenhouse-grown plants maintained with natural light and controlled temperature at $25 \pm 1^{\circ} \mathrm{C}$. ' $C a$. L. asiaticus'-infected Valencia sweet orange (Citrus sinensis 'Valencia') was used in the optimization process of PMA-qPCR protocol and in the monthly monitoring of GLB dynamics. Healthy Valencia sweet orange grown from seed and kept in a separate greenhouse were confirmed to be HLB negative by qPCR first (21), then used as a healthy control in all qPCR reactions. For the study of GLB in different host plants of ' $\mathrm{Ca}$. L. asiaticus', leaves from at least three individual plants of each plant species or cultivar were used. The plants used in the cultivar experiment included Navel sweet orange ( $C$. sinensis 'Bahia'), Benton citrange $(C . \times$ insitorum Mabb. 'Benton'), Carrizo citrange $(C$. $\times$ insitorum Mabb. 'Carrizo'), Kohorski sour orange (C. aurantium L.), Mexican lime (C. aurantifolia (Christm.) Swingle), Cleopatra mandarin (C. reticulata 'Blanco'), Rough lemon $(C . \times$ jambhiri Lush. 'Rough lemon'), $C$. indica Tanaka, Volkamer lemon $(C$. limonia Osbeck 'Volkameriana'), Duncan grapefruit (C. paradisi MacFadyen), Valencia sweet orange (C. sinensis Valencia), Kikojii Flame grapefruit ( $C$. paradisi 'Flame'), Iapar sweet orange $(C$. sinensis 'Iapar'), Pineapple sweet orange ( $C$. sinensis 'Pineapple'), Madam Vinous sweet orange ( $C$. sinensis 'Madam Vinous'), Hamlin sweet orange $(C$. sinensis 'Hamlin'), Calamondin $(\times$ Citrofortunella microcarpa), Severinia buxifolia, Zanthoxylum fagara, Murraya paniculata, periwinkle (Catharanthus roseus), and dodder (Cuscuta indecora).

Healthy ACP (D. citri) were collected from M. paniculata ornamentals located in Winter Haven, FL, and released in a 60-by-60by-90-cm Rearing and Observation Cage (BioQuip Products Inc.) with multiple flushing plants, including sweet orange (Citrus sinensis) and M. koenigii (syn. Bergera koenigii) (marked and referred to as 'healthy cage'). ' $\mathrm{Ca}$. L. asiaticus'-positive psyllids were collected from HLB-positive citrus groves in Winter Haven,
FL and released on citrus plants which were kept in a specialized psyllid room with a controlled temperature of $25 \pm 1^{\circ} \mathrm{C}$ and controlled light of $12 \mathrm{~h}$ of artificial light exposure each day. Psyllid colonies were established at both sites and constantly monitored by qPCR. Healthy control psyllids were collected from the healthy cage, while ' $C a$. L. asiaticus'-positive psyllids from the psyllid room were used in microscopic observation and comparison work with PMA-qPCR.

PMA-qPCR protocol. For plant materials, midribs and petioles from randomly collected leaves were used for total DNA extraction. After being chopped into small pieces (about $0.5 \mathrm{~mm}$ long) with sterile razor blades, about $120 \mathrm{mg}$ of plant tissue (more than the required $100 \mathrm{mg}$ of tissue to compensate any material loss during the process) was put into Eppendorf tubes and treated by TissueLyser II (TL) (Qiagen) with liquid nitrogen (LN); the pulverized tissue powder was then taken out of the tube and put onto a piece of wax paper where it was mixed again with a toothpick to make a homogenized tissue pool; two portions of 50 mg of tissue powder from the pool were weighed out, each portion was put into a new Eppendorf tube, and $1 \mathrm{ml}$ of sterile distilled water (SDW) was added into the tube and mixed briefly by vortexing. After this step, two tubes containing the same amount of starting plant tissue $(50 \mathrm{mg}$ each) were obtained from each test sample and ready for the following different treatments.

A stock solution of PMA (Biotium Inc.) at $10 \mathrm{mg} / \mathrm{ml}$ was made with SDW. PMA is photosensitive; therefore, the stock solution was kept in light-tight tubes and stored at $4^{\circ} \mathrm{C}$. The PMA stock solution $(2.5 \mu \mathrm{l})$ was added into one of the two tubes in the dark to a final concentration of $25 \mu \mathrm{g} / \mathrm{ml}$ (about $50 \mu \mathrm{M}$ PMA), then mixed briefly by inverting the tube. PMA treatment was to quantify GLB; therefore, to quantify the total genome present (TGP; the combination of live and dead cells) in the sample, no PMA was added to the other tube in this step. The physical treatments such as vortexing and incubation were the same for both tubes. The tubes were then incubated at room temperature in the dark for 5 min with occasional inversion. After incubation, the tubes were briefly vortexed for $5 \mathrm{~s}$ and placed into crushed ice with their lids off and exposed to light from a halogen bulb $(650 \mathrm{~W})$ for $2 \mathrm{~min}$ at a distance of $20 \mathrm{~cm}$ from the light source. The tubes were then centrifuged at $13,200 \mathrm{rpm}(16,100 \times \mathrm{g})$ for $5 \mathrm{~min}$, and $800 \mu \mathrm{l}$ of the supernatant was removed. The pellet with the remaining liquid was used to extract total DNA with a DNeasy Plant Mini Kit (Qiagen) following the manufacturer's instructions, with a minor modification in the last step, where only $50 \mu$ l of elution buffer AE was used to obtain the final DNA sample.

For psyllid material, a single psyllid was put into a $1.5-\mathrm{ml}$ Eppendorf tube with $100 \mu \mathrm{l}$ of SDW and ground with a pestle to homogenize the sample. The sample $(50 \mu \mathrm{l})$ was transferred into a new 1.5-ml Eppendorf tube and $50 \mu \mathrm{l}$ of SDW was added for a total volume of $100 \mu \mathrm{l}$. As described for plant material, two tubes with the same amount of psyllid material in $100 \mu \mathrm{l}$ of suspension were obtained for each psyllid sample tested. The two tubes were vortexed briefly; then, PMA was added into one tube in the dark to a final concentration of $25 \mu \mathrm{g} / \mathrm{ml}$ to obtain GLB data whereas, for TGP data, no PMA was added in this step. The tubes were incubated at room temperature in the dark for $5 \mathrm{~min}$ with occasional inversion. Then, after a brief vortex $(5 \mathrm{~s})$, the tubes were set into crushed ice with their lids off and exposed to light from a halogen bulb $(650 \mathrm{~W})$ for $2 \mathrm{~min}$ at a distance of $20 \mathrm{~cm}$ from the light source. The tubes were briefly vortex mixed again and the whole suspension (about $100 \mu \mathrm{l}$ ) was used for total DNA extraction with DNeasy Blood \& Tissue Kit (Qiagen) following the manufacturer's instructions, with minor modification as described above.

After the total DNA was extracted, the yield and purity of the DNA samples were determined with a NanoDrop Spectrophotometer ND-1000 and all DNA samples were stored at $-20^{\circ} \mathrm{C}$.

qPCR. In this study, citrus material was used in the optimization process of the PMA-qPCR working protocol whereas, in the part where microscopic work was involved, psyllid material was preferred, considering the high bacterial populations and low host 
tissue background (9). Based on the different materials used in this study, two previously published qPCR systems for ' $C a$. L. asiaticus' detection were employed. For plant material, a duplex TaqMan qPCR system was utilized (21). In this duplex qPCR, two primerprobe sets of HLBasrp (designed based on 16S rDNA of ' $\mathrm{Ca}$. L. asiaticus' genome) and COXfpr (designed based on citrus mitochondrial cytochrome oxidase gene and used as positive internal control to assess the quality of the DNA extracts and reaction mixtures) were used (Table 1). For psyllid material, another duplex TaqMan qPCR system, including the HLBasrp set for ' $\mathrm{Ca}$. L. asiaticus' (21) and the WGfrp set for internal control of psyllid material (based on wingless gene coding a glycoprotein of the psyllid species) (24), was used (Table 1).

Both qPCR reactions were performed on an Applied Biosystems 7500 Fast Real-Time PCR System (Life Technologies) and shared the same protocol, as follows: $2 \mathrm{~min}$ of incubation at $50^{\circ} \mathrm{C}$ followed by $10 \mathrm{~min}$ of incubation at $95^{\circ} \mathrm{C}$; then, 40 cycles of $15 \mathrm{~s}$ at $95^{\circ} \mathrm{C}$ and $1 \mathrm{~min}$ at $60^{\circ} \mathrm{C}$; fluorescent signals were collected at the $1 \mathrm{~min}$ at $60^{\circ} \mathrm{C}$ stage of each cycle. The $20-\mu \mathrm{l}$ qPCR reaction mixture contained $10 \mu \mathrm{l}$ of $2 \times$ ABI TaqMan Universal PCR Master Mix (Life Technologies), $2 \mu$ l of DNA template, appropriate amount of primer/probe stock (to reach the optimized final concentrations as reported), and Nuclease-Free Water (Qiagen). All reactions were performed in triplicate, and each run contained one negative, one positive, and one healthy control. qPCR data were analyzed with the Applied Biosystems software (version 1.4.0.). Statistical analysis of the qPCR data was done with SAS 9.3 TS Level 1M0, and analysis of variance with Tukey's Studentized range (HSD) test was done at the significant level of $P<0.05$.

PMA-qPCR optimization. The working protocol which was originally designed for bacterial cultures $(29,39)$ was used as a prototype for PMA-qPCR in this study but, later, several major modifications were made. The modifications were validated with parallel experiments, in which only the modified step was different while the rest of the protocol remained the same.

The effect of TL treatment was tested as follows. Starting from a raw sample pool of $350 \mathrm{mg}$ of chopped citrus midrib or petiole tissue, three aliquots of $50 \mathrm{mg}$ of tissue were first weighed out and put into three individual 1.5-ml Eppendorf tubes. The three tubes then went directly to the DNA extraction steps with DNeasy Plant Mini Kit (Qiagen) and the samples extracted in this way were referred to as "without TL". Then, the rest of the chopped materials in the raw pool (about $200 \mathrm{mg}$ of tissue left) were processed by TissueLyser II (Qiagen) with LN, after which three aliquots of 50 $\mathrm{mg}$ of tissue were weighed out from the pulverized tissue pool, put into three tubes, and used for DNA extraction; the second batch of three DNA extracts were referred to as "with TL". The same parallel experiment was repeated three times with different tissue sam- ples, and the quantitative cycle $(\mathrm{Cq})$ values from these DNA extracts were compared.

Different final concentrations of PMA and EMA used in the pretreatment were compared in this study. EMA powder (Molecular Probes, Inc.) was used to prepare a stock solution of $10 \mathrm{mg} / \mathrm{ml} \mathrm{in}$ SDW in the dark. Starting from a sample pool of pulverized citrus midrib or petiole tissue, portions of $50 \mathrm{mg}$ of tissue were weighed out and put into 1.5-ml Eppendorf tubes with $1 \mathrm{ml}$ of SDW, which then received the same processing steps as in the optimized working protocol to get DNA extracts which differed only in the amount of PMA (or EMA) added. The different amounts of PMA (or EMA) tested were $0.5,2.5$, and $10 \mu \mathrm{l}$ of a stock solution at 10 $\mathrm{mg} / \mathrm{ml}$ to reach final concentrations of 5,25 , and $100 \mu \mathrm{g} / \mathrm{ml}$, respectively. Each sample which received different amounts of PMA (or EMA) had three replicates from the same sample pool. In the data analysis, a comparison was made between different "DNA yield in percent", which showed a general DNA removal efficiency after PMA (or EMA) treatment. First, the Cq values obtained from PMA (or EMA) treated and untreated samples were converted into

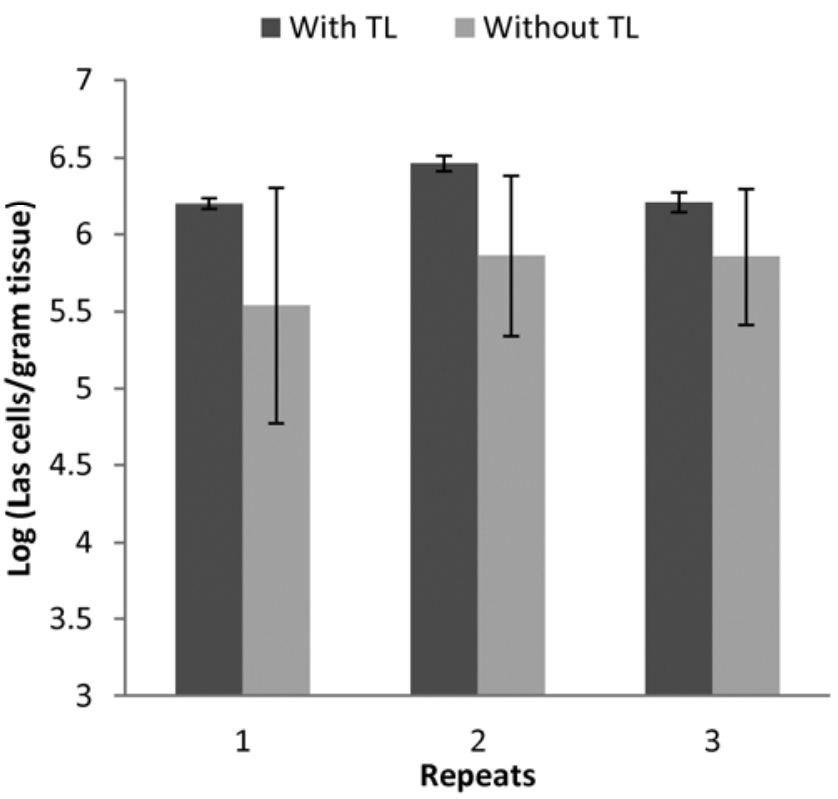

Fig. 1. Effect of TissueLyser pretreatment (TL) in quantitative polymerase chain reaction (qPCR) assays for 'Candidatus Liberibacter asiaticus'. Aliquots from the same plant sample were treated with or without TissueLyser and tested with qPCR after DNA extraction. No propidium monoazide treatment was included in this experiment. Error bars represented standard deviations from three replicates, and the experiment was repeated three times.

Table 1. Primers and probes used in quantitative real-time polymerase chain reaction

\begin{tabular}{|c|c|c|c|c|c|c|}
\hline System & $\begin{array}{c}\text { Primer, } \\
\text { probe }\end{array}$ & Sequence $\left(5^{\prime} \rightarrow 3^{\prime}\right)$ & Region & $\begin{array}{l}\text { Conc. } \\
(\mathbf{n M})^{\mathrm{a}}\end{array}$ & $\begin{array}{l}\text { Eff. } \\
(\%)^{b}\end{array}$ & Source \\
\hline \multirow[t]{3}{*}{ HLBasrp } & HLBas & TCGAGCGCGTATGCAATACG & $16 \mathrm{~S}$ rDNA & 250 & 98.2 & 21 \\
\hline & $\mathrm{HLBr}$ & GCGTTATCCCGTAGAAAAAGGTAG & $\ldots$ & 250 & $\ldots$ & $\ldots$ \\
\hline & $\mathrm{HLBp}^{\mathrm{c}}$ & (FAM)-AGACGGGTGAGTAACGCG-(BHQ-1) & $\ldots$ & 150 & & $\ldots$ \\
\hline \multirow[t]{3}{*}{ COXfrp } & COXf & GTATGCCACGTCGCATTCCAGA & Cytochrome oxidase (COX) gene & 300 & 91.6 & 21 \\
\hline & $\mathrm{COXr}$ & GCCAAAACTGCTAAGGGCATTC & $\ldots$ & 300 & $\ldots$ & $\ldots$ \\
\hline & $\operatorname{COXp}^{\mathrm{c}}$ & (TET)-ATCCAGATGCTTACGCTGG-(BHQ-2) & $\ldots$ & 150 & $\ldots$ & $\ldots$ \\
\hline \multirow[t]{3}{*}{ WGfrp } & WGf & GCTCTCAAAGATCGGTTTGACGG & Glycoprotein gene wingless ( $w g$ ) & 300 & 97.0 & 24 \\
\hline & WGr & GCTGCCACGAACGTTACCTTC & $\ldots$ & 300 & $\ldots$ & $\ldots$ \\
\hline & $\mathrm{WGp}^{\mathrm{c}}$ & (TET)-TTACTGACCATCACTCTGGACGC-(BHQ-2) & & 150 & & \\
\hline \multirow[t]{3}{*}{ pthfrp } & J-RTpth3 & ACCGTCCССТАСТTCAАCTCAA & Pathogenicity gene $(p t h)$ & 400 & 103.0 & 7 \\
\hline & J-RTpth4 & CGCACCTCGAACGATTGC & $\ldots$ & 400 & $\ldots$ & $\ldots$ \\
\hline & J-Taqpth $2^{c}$ & (FAM)-ATGCGCCCAGCCCAACGC-(TAMRA) & $\ldots$ & 200 & $\ldots$ & $\ldots$ \\
\hline
\end{tabular}

${ }^{a}$ Final concentration.

${ }^{\mathrm{b}}$ Primer efficiency. Ten-time serial dilutions were made from propidium monoazide-treated DNA extractions of plant, psyllid, and Xanthomonas citri subsp. citri samples, respectively, and tested in quantitative polymerase chain reaction to generate standard curves. Primer efficiencies of each primer/probe set were calculated from the slope of each of the standard curves with the formula $10^{-(1 /- \text { Slope })}-1$.

c TaqMan probes. 
bacterial cell numbers by the standard curve developed in this study; then, the cell numbers of PMA (or EMA)-treated samples were divided by those of untreated samples, which resulted in the DNA yield. Based on the calculation process of the "DNA yield in percent", it can be also considered as the live bacterial percentage in the total population.

Effect of TL with LN treatment on GLB. The effect of physical disruption (PD) and LN treatment on the GLB was studied as follows. Sixteen mature HLB-affected leaves with typical blotchy mottle symptoms were collected and a sample pool (about $1.6 \mathrm{~g}$ in total) was made by chopping midribs and petioles. The sample pool was divided into four portions ( $0.4 \mathrm{~g}$ per portion), and each portion was then further divided into three equal samples $(0.13 \mathrm{~g}$ per sample). Each portion of three samples received different treatments: (i) no LN + PD (untreated sample as negative control), (ii) LN (the sample tubes were placed in LN; no PD with a bead beater), (iii) PD (samples in tubes received only PD in TL with metal beads; no LN treatment prior to this), and (iv) with $\mathrm{LN}+\mathrm{PD}$ (sample tube first placed in LN, then disrupted in TL with metal beads, the regular TL treatment as in PMA pretreatment). After the different treatments, two aliquots of $0.05 \mathrm{~g}$ of tissue were weighed out from each sample and placed into individual Eppendorf tubes. PMA was added to one tube; no PMA was added to the other one, which then would receive the rest of the PMA pretreatment process as described in the PMA-qPCR protocol above. The whole process was repeated three times, and all the leaves from each of the three replicates were sampled from the same ' $C a$. L. asiaticus'-positive citrus plant.

Interference of plant tissue with PMA-qPCR. To determine whether citrus leaf tissue interfered with our PMA protocol, a culturable pathogen, Xanthomonas citri subsp. citri, was assayed with and without citrus tissue present. $X$. citri subsp. citri strain 306 was used in this study. The bacterium was grown in nutrient broth on a shaker at $200 \mathrm{rpm}$ and $28^{\circ} \mathrm{C}$ overnight to the log phase. Bacterial cells were collected by centrifugation at $5,000 \times g$ for $5 \mathrm{~min}$ and resuspended in SDW. The bacterial cell suspension was adjusted to an optical density at $600 \mathrm{~nm}$ of 0.03 by dilution with SDW. The bacterial suspension was killed by exposure to isopropanol (final concentration, $70 \%$ ) for $10 \mathrm{~min}$, and mixed with a fresh culture suspension at the defined ratios of viable versus isopropanol-killed as follows: 1,000:0, 900:100, 500:500, 100:900, and 0:1000 (29). The isopropanol-killed cells were checked for viability by plating on nutrient agar, followed by two to three days of incubation at $28^{\circ} \mathrm{C}$.
Leaf samples collected from healthy citrus trees were pulverized by TL with LN. Aliquots of $50 \mathrm{mg}$ of tissue powder from the same sample pool were weighed out and put into individual $1.5-\mathrm{ml}$ Eppendorf tubes. The bacterial suspension $(1 \mathrm{ml}$ of each mixed ratio) was added to two tubes of plant tissue. One tube was subject to PMA treatment (as for GLB) and the other one was treated the same, only without PMA added (as for TGP). PMA-qPCR pretreatment was followed by DNA extraction and qPCR. Three replicates were included for each bacterial suspension. In the qPCR system, the pthfrp set of primers/probe (Table 1) was designed based on sequences of the pth gene (8), a major virulence gene used specifically to detect strains of citrus bacterial canker $(6,26)$. The COXfrp set (21) was also included in this qPCR as internal control for plant material. The reaction mixture, machine, qPCR protocol, and data analysis were similar to that described for determining the GLB of ' $\mathrm{Ca}$. L. asiaticus'. After qPCR, the numbers of live and dead cells were first calculated from the $\mathrm{Cq}$ values with the standard curve method (7), and the ratios were compared with the original defined ratios.

PMA-qPCR versus bacterial rods/field. Psyllids were collected from our psyllid colony and immobilized by putting them in a $-20^{\circ} \mathrm{C}$ freezer for $15 \mathrm{~min}$. For surface cleaning, psyllids were first washed with $70 \%$ ethanol once, then rinsed with SDW 15 to 20 times. The psyllids were dissected under a dissecting microscope and the alimentary canals were removed and transferred into a $0.5-\mathrm{ml}$ PCR tube with $30 \mu \mathrm{l}$ of SDW (one alimentary canal in each tube). After vortex mixing for $1 \mathrm{~min}$ and a brief centrifugation, the alimentary canal was pipetted out along with $1 \mu \mathrm{l}$ of the liquid. PMA was added to the tube (final concentration $=25$ $\mu \mathrm{g} / \mathrm{ml}$ ) and incubated for $5 \mathrm{~min}$ in the dark. Buffer from the tube $(4 \mu \mathrm{l})$ was pipetted onto a slide, stained with $1 \mu \mathrm{l}$ of a $25-\mu \mathrm{M}$ SYTO 13 Green Fluorescent Nucleic Acid Stain (Molecular Probes, Invitrogen), and mounted for direct counting with an Axio Imager A1 Microscope (Carl Zeiss) using a green fluorescence Filter Set 38 (excitation: 470/40 nm; emission: 525/50 $\mathrm{nm})$. Photomicrographs were taken with an AxioVision LE camera attached to the microscope using the green fluorescence Filter Set 38 (for SYTO 13, excitation/emission maximum = $488 / 506 \mathrm{~nm}$ ) and the red fluorescence Filter Set 20 (for PMA, excitation/emission maximum: 464/610 nm; parameters for Filter Set 20, excitation: 546/12, emission: 608/32), respectively. The software used for visualization was AxioVision LE, Release 4.6 (Carl Zeiss). The remaining liquid in the tube (about $25 \mu \mathrm{l}$ )

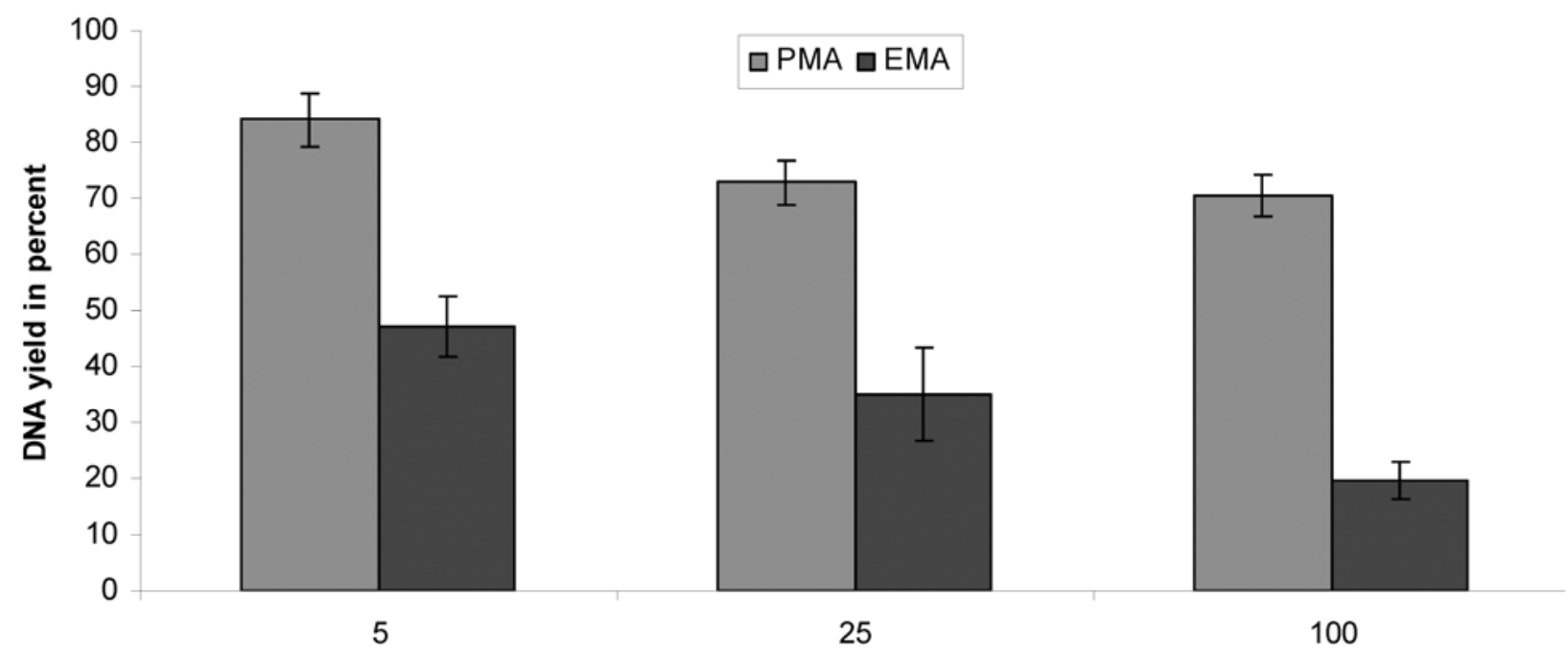

Final concentration $(\mu \mathrm{g} / \mathrm{mL})$

Fig. 2. Effect of different concentrations of propidium monoazide (PMA) or ethidium monoazide (EMA) on DNA yields. Sample aliquots were made from the same sample pool, and treated with PMA (or EMA) at different final concentrations. First, Cq values obtained from PMA (or EMA- treated and untreated samples were converted into bacterial cell numbers with a standard curve; then, cell numbers of PMA (or EMA)-treated samples were divided by those of untreated samples, which resulted in the DNA yield. Error bars represented standard deviations from three replicates. 
followed the PMA-qPCR protocol for psyllid samples, as described above.

For direct counting, a 10X/23 eyepiece and a 63X/1.25 Oil Iris objective lens were chosen as the working combination. Twenty fields were randomly screened and only typical rod-shaped Liberibacter bacteria were counted toward a total number, based on which a "rods per field" number was first calculated (total number/20) and then converted into "rods per microliter of liquid" with the microscopic parameters. The logarithmic values of rods per microliter of liquid data were then plotted against $\mathrm{Cq}$ values of each of the corresponding psyllid DNA extracts in $\mathrm{qPCR}$, and linear regression was used to help find a possible correlation (i.e., standard curve).

GLB dynamics in Valencia sweet orange. Valencia seedlings (2-months after transplant) were initially inoculated with ' $C a$. L. asiaticus'-positive psyllids in November 2009. After being confirmed as ' $\mathrm{Ca}$. L. asiaticus' positive by qPCR, three seedlings were tested monthly with PMA-qPCR beginning in August 2010. The monitoring lasted for about 20 months, until April 2012. The average $\mathrm{Cq}$ values obtained from the three Valencia seedlings were first converted to GLB and TGP data with the standard curve, then plotted over the time period to check the dynamic change of bacterial population in plant host.

\section{Results}

PMA-qPCR optimization. Compared with the sample treated without TL treatment, a higher number of bacterial genomes was detected with TL treatment, which could be caused by more bacteria being released from the smaller leaf tissue particles (Fig. 1). More importantly, the standard deviation was smaller among the samples that received TL treatment, demonstrating greater homogeneity in the sample pool.

Series of different final concentrations of PMA and EMA (5, 25, and $100 \mu \mathrm{g} / \mathrm{ml}$ ) were tested and compared in order to find the best working concentration for this assay. Starting with the same tissue sample pool, more DNA was removed by EMA treatment than was removed by PMA at the same concentration (Fig. 2). More DNA was removed as EMA concentrations increased. However, DNA removal by PMA did not increase when dye concentration exceeded $25 \mu \mathrm{g} / \mathrm{ml}$. Therefore, the final concentration of $25 \mu \mathrm{g} / \mathrm{ml}$ PMA was chosen in the working protocol.

Effects of TL treatment on GLB. The four different treatments gave significantly different estimates of ' $\mathrm{Ca}$. L. asiaticus' genome when used on samples from the same plant (HSD test, $P<0.05$ ). Compared with untreated samples, low-temperature treatment (using $\mathrm{LN}$ as in "With LN" and "With LN + PD") did not cause any significant change (or loss) in the resulting genome but PD alone (using TL machine without LN as in "With PD") caused a significant rise in $\mathrm{Cq}$ value, which meant a significant loss in the GLB detected (Fig. 3). At the same time, samples that received the two treatments separately ("With LN" or "With PD") resulted in significantly lower GLB than the ones with two treatments together (i.e., the regular TL treatment as in "With LN + PD"). For the TGP, compared with samples with no treatment, each treatment alone ("With LN" or "With PD") did not have significant impact on the TGP detected, whereas combined treatments resulted in a significantly higher TGP. Most of the groups (four different treatments in live and total) had considerable variations within the data collected from nine samples (three samples from each of the three repeats), while only the GLB obtained with regular TL treatment had the smallest variations (Fig. 3).

Determination of interference of plant tissue with PMAqPCR. After exposure to isopropanol for $10 \mathrm{~min}$, the viability

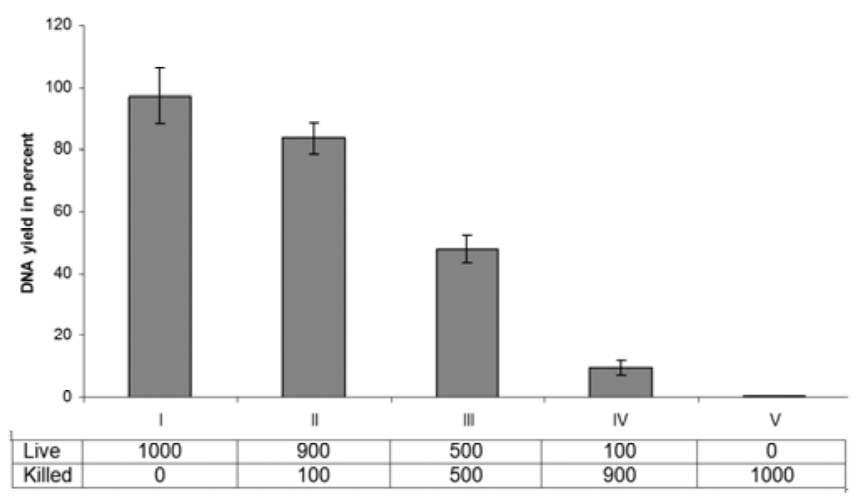

Fig. 4. Propidium monoazide quantitative polymerase chain reaction (PMA-qPCR) with defined ratios of live and isopropanol-killed Xanthomonas citri subsp. citri. The table shows the ratios of live and isopropanol-killed bacteria. Numbers represent volumes in microliters. One milliliter of mixed bacterial suspension was mixed with $50 \mathrm{mg}$ of plant tissue to mimic the situation of 'Candidatus Liberibacter asiaticus'infected plant samples. After PMA-qPCR procedure, the DNA yields (in percent) were compared with predefined ratios. Error bars represented the standard deviations from three replicates.

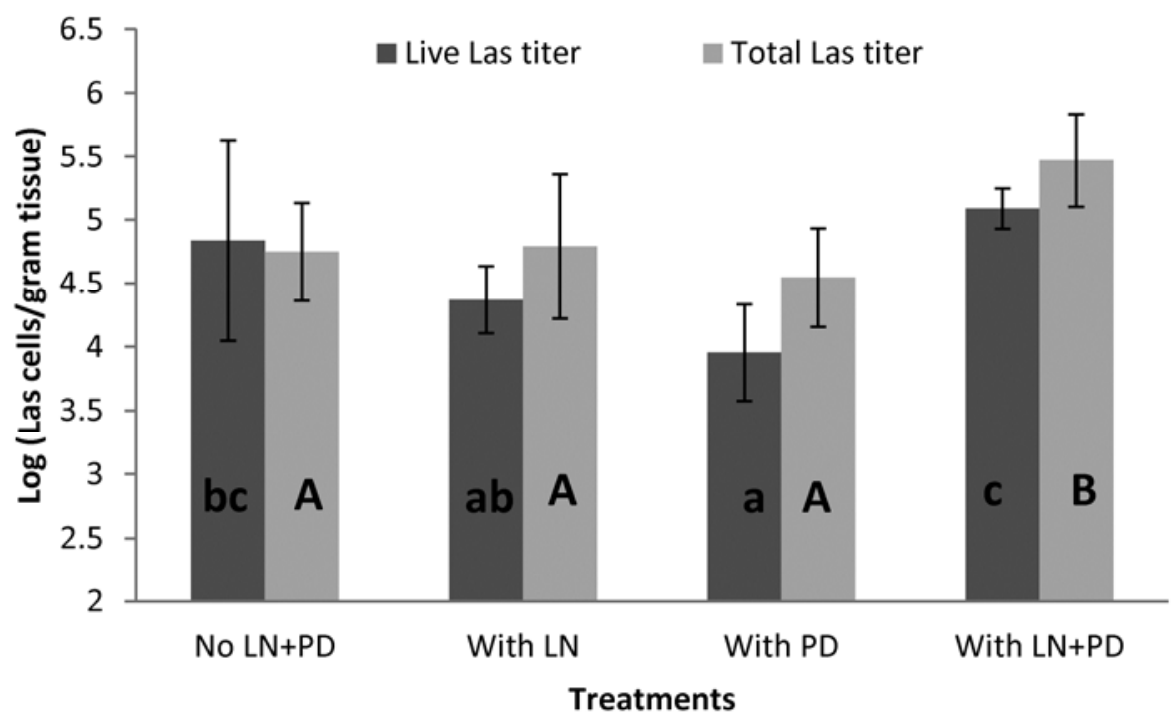

Fig. 3. Effects of TissueLyser treatment on the quantification of live and total 'Candidatus Liberibacter asiaticus' (Las) genome by quantitative polymerase chain reaction propidium monoazide quantitative polymerase chain reaction (PMA-qPCR). Aliquots from the same sample pool received different treatments; that is, with either liquid nitrogen ( $L N)$ or physical disruption (PD, treated with metal beads pounding), with both $L N+P D$, or without $L N+P D$. After the four treatments, all aliquots of samples were tested following the same PMA-qPCR protocol, and the resulting Cq values of genomes from live bacteria (GLB) and total genome present (TGP) were compared. Lowerand uppercase letters in the columns indicate the significance within GLB and TBP, respectively. Error bars represented standard deviations from nine replicates of each sample (three replicates from three repeated experiments). 
check by plating on nutrient agar showed no X. citri subsp. citri colonies after 3 days of incubation. The isopropanol-killed cells were mixed with the untreated original culture in defined ratios (Fig. 4, table), and then $1 \mathrm{ml}$ of the mixed bacterial suspension was added to $50 \mathrm{mg}$ of pulverized plant tissue and the mixture was treated following the PMA-qPCR protocol, which resulted in two $\mathrm{Cq}$ values representing GLB and TGP, respectively. The "DNA yield in percent" was compared with the defined ratios. With an increase of dead cells in the bacterial suspension, the $\mathrm{Cq}$ values of the GLB also increased (representing a decrease in detectable GLB) while the TGP (from samples without PMA) remained unchanged. As a result, with three replicates, the "DNA yield in percent" data agreed well with the defined ratios (Fig. 4).

PMA-qPCR versus direct counting with microscope. For direct counting (Fig. 5A, live bacteria observed with green fluorescence filter set 38), rods/field data were first converted to rods/microliter using parameters from the microscope and then the logarithmic values of the rods/microliter data were plotted against $\mathrm{Cq}$ values from qPCR (Fig. 6). A standard curve by linear regression showed a good fit of the data, and the $R^{2}$ value of 0.9476 indicated a good accuracy over a relatively wide range of $\mathrm{Cq}$ values (from 26 to 34). With the standard curve in Figure 6, an estimation of the live ' $\mathrm{Ca}$. L. asiaticus' genome, or how many live Liberibacter rods could be observed under the microscope, can be made based on a $\mathrm{Cq}$ value obtained by PMA-qPCR, or vice versa. Furthermore, the standard curve could be further converted to show the $\log$ value of bacterial cells per gram of plant tissue versus $\mathrm{Cq}$ values, which is $y=-0.2819 x+13.576$, where $y=\log$ value of bacterial cells per gram of tissue and $x=\mathrm{Cq}$.

PMA-qPCR on different host plants. Whether or not different host plants which showed different levels of resistance to HLB disease also had different levels of GLB was determined for 24 citrus and non-citrus plants infected with ' $\mathrm{Ca}$. L. asiaticus'. A range of GLB among individual plants was obtained in most of the hosts tested (Fig. 7), which made the difference among different citrus varieties insignificant, and this insignificant difference was also observed in TGP (data not shown). However, some significant differences still existed; for example, dodder (Cuscuta indecora) had a significantly higher amount of GLB than the rest, whereas $M$. paniculata and $Z$. fagara had significantly lower amounts of GLB compared with the citrus genotypes $(P<0.0001)$.

GLB dynamics in ' $\mathrm{Ca}$. L. asiaticus'-infected sweet orange. The GLB in the three Valencia seedlings started at a lower level and this lower level lasted about 8 months, until April 2011, when the GLB had a sudden rise of more than 60 times and stayed on a significant higher level (Fig. 8; Turkey's HSD test, $P<0.05$ ). However, in contrast to this seasonal development found in the GLB, no obvious pattern was observed in the TGP throughout the entire 20month period.

\section{Discussion}

PMA-qPCR optimization. Unlike PMA, EMA was reported to be problematic when used to selectively remove DNA of dead cells $(4,10,19,29)$. EMA could pass through intact cell membranes of live cells of many different bacterial species tested, and cause DNA loss in both DNA extraction and subsequent PCR assays, whereas no staining of DNA of live bacteria was observed with PMA (29). Therefore, PMA was chosen to work with qPCR in this study to gain a better understanding of GLB in HLB-affected hosts. However, direct utilization of the published EMA-qPCR or PMA-qPCR working protocols $(29,39)$ in this study led to inconsistent results. For example, a large variation of $\mathrm{Cq}$ values was observed among aliquots from the same sample pool which rendered results unreliable. After PMA pretreatment, ' $\mathrm{Ca}$. L. asiaticus' was sometimes not detected in previously positive plant samples, which made the data useless. The previous working protocol of PMA-qPCR was originally designed for culturable bacteria and, therefore, had fewer variables to control compared with uncultured ' $\mathrm{Ca}$. L. asiaticus'. In addition, no protocol was available for working with psyllid material. Therefore, optimization of the previous working protocols was necessary.
In order to get a more accurate estimate of live ' $\mathrm{Ca}$. L. asiaticus' genome in the hosts, a homogeneous starting material is quite important. For plant materials, finely chopped midrib and petiole tissue is good enough for a positive or negative result; however, whether the roughly treated material could meet the needs of qPCR

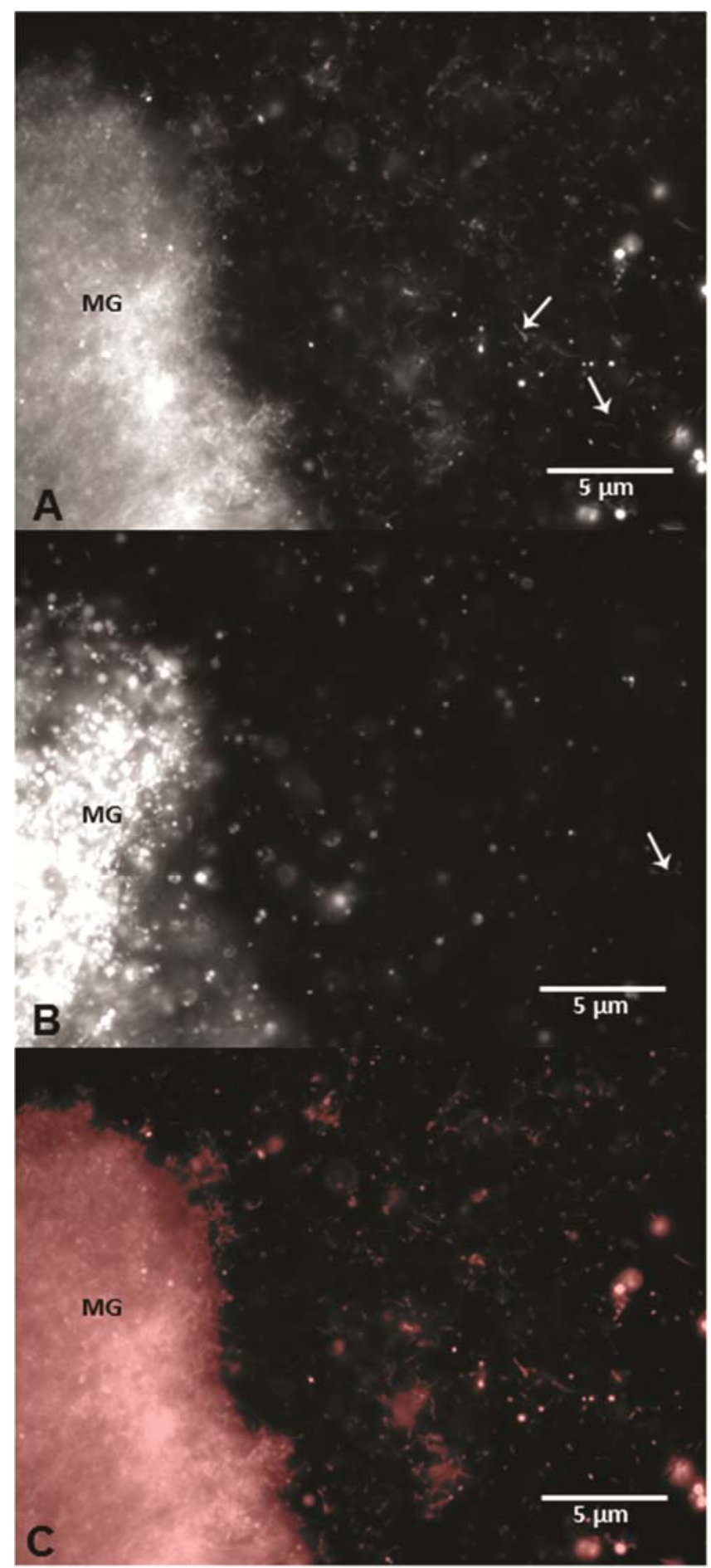

Fig. 5. 'Candidatus Liberibacter asiaticus' observed under fluorescent microscope stained with both SYTO 13 and propidium monoazide (PMA). SYTO 13 stains live and dead bacterial cells, whereas PMA only stains dead cells. Stains vary in excitation and emission wavelengths, allowing live and dead cells to be visualized with two different filter sets. Three figures showed the same field under the microscope, and the midgut (MG) on the left side of each figure was used as reference object. As indicated by arrows, typical long, thin, rod-shaped ' $\mathrm{Ca}$. $\mathrm{L}$. asiaticus' (about 1,000 $\mathrm{nm}$ in length and $200 \mathrm{~nm}$ in width) were counted in the microscopic-counting experiment. A, Filter set 38 for SYTO 13 view of live cells (in black/white); B, filter set 20 for PMA view of dead cells (in black/white); and C, black/white SYTO 13 view of live cells overlaid by colorized PMA view of dead cells. 
or PMA-qPCR was in question. Due to the fact that ' $\mathrm{Ca}$. Liberibacter spp.' are inside the plant phloem tissue, and that they are unevenly distributed in planta $(3,35)$, a severe disruption protocol was needed to minimize these effects. Therefore, a pulverization step using TL and LN was added to reduce the tissue particle size and make a more uniform sample pool. The results not only showed that pulverized tissue had less variation among portions from the same pool but also gave a higher DNA extraction efficiency, demonstrated by a generally higher bacterial DNA concentration from pulverized tissue compared with the same sample without pulverization (Fig. 1). The increased DNA extraction effi- ciency could help minimize experimental error and, thus, is an additional value of the TL step.

In previous EMA or PMA work published, different final concentrations were used for different target bacteria or specific applications, which made it uncertain which concentration would work for ' $C a$. L. asiaticus'. For example, EMA was used at the final concentration of $240 \mu \mathrm{M}$ (about $100 \mu \mathrm{g} / \mathrm{ml})(27,34,39)$ and $50 \mu \mathrm{M}$ (about $25 \mu \mathrm{g} / \mathrm{ml}$ ) (29). PMA was mostly used at 50 and $5 \mu \mathrm{M}$ $(23,29)$. All of the published PMA work dealt with pure bacterial cultures rather than uncultured bacteria such as ' $\mathrm{Ca}$. L. asiaticus'. Because these concentrations might not work the same with ' $\mathrm{Ca}$.

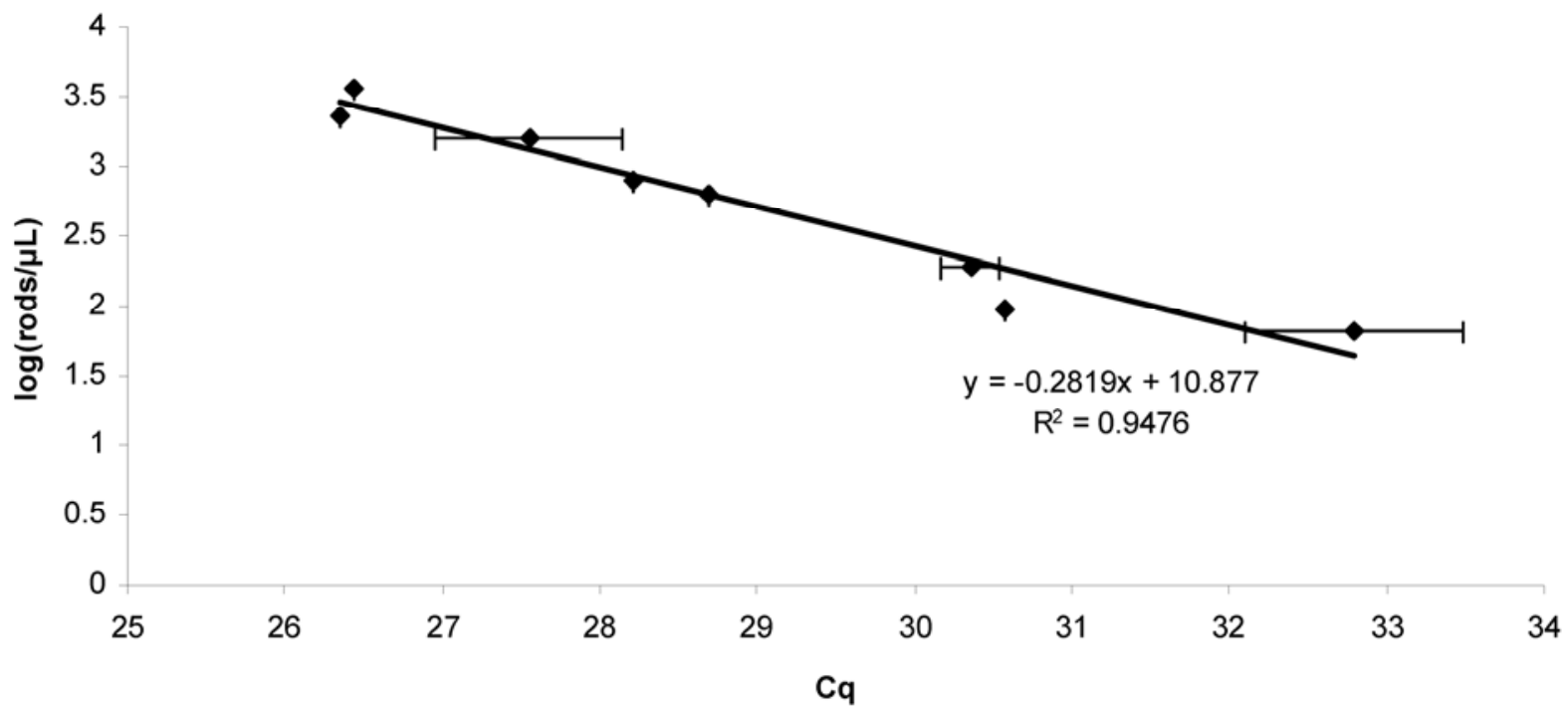

Fig. 6. Correlation between log value of bacterial concentration from microscopic counting and $\mathrm{Cq}$ values obtained by propidium monoazide quantitative polymerase chain reaction (PMA-qPCR). Psyllid samples were first dissected, and the suspension of the alimentary canal was observed with the microscope as well as tested by qPCR after treatment with both SYTO 13 and PMA. Log values of bacterial concentrations from microscopic observation were plotted against the corresponding Cq values obtained from qPCR, and the linear regression resulted in a standard curve as above. Error bars represented standard deviations from at least three replicates.

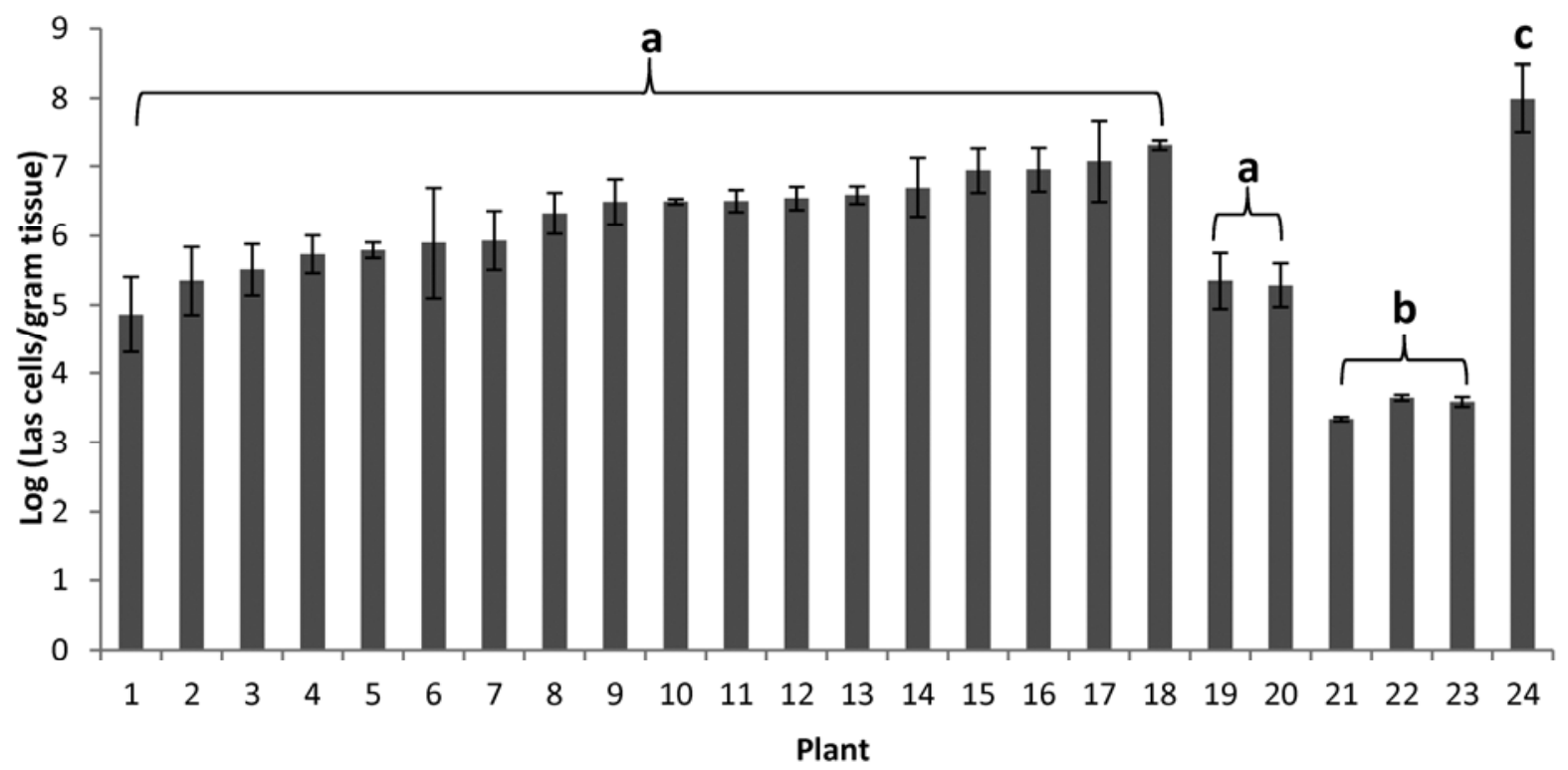

Fig. 7. Comparison of the live 'Candidatus Liberibacter asiaticus' (Las) genome in 24 different host plants. Plants 1 to 18 were different citrus varieties and species. Plants 19 to 24 were citrus relatives or other plant species. Error bars represented standard deviations among three to eight plants of each cultivar or species tested. Analysis of variance with Tukey's Studentized range (HSD) test was done at the significance level of $P<0.05$. Letters show the significant difference between bracketed groups, while no significant difference was found within each bracketed group. Species: 1, Navel sweet orange (Citrus sinensis 'Bahia'); 2, Benton citrange (C. × insitorum Mabb. 'Benton'); 3 , Carrizo citrange (C. x insitorum Mabb. 'Carrizo'); 4, Kohorski; 5, Sour orange (C. aurantium L.); 6 , Mexican lime (C. aurantifolia (Christm.) Swingle); 7 , Cleopatra mandarin (C. reticulata Blanco); 8, Rough lemon (C. × jambhiri Lush. Rough lemon); 9, C. indica Tanaka; 10, Volkamer Lemon (C. limonia Osbeck 'Volkameriana'); 11, Duncan grapefruit (C. paradisi MacFadyen); 12, Valencia sweet orange (C. sinensis 'Valencia'); 13, Kikojii; 14, Flame grapefruit (C. paradisi 'Flame'); 15, lapar sweet orange (C. sinensis 'lapar'); 16, Pineapple sweet orange (C. sinensis 'Pineapple'); 17, Madam Vinous sweet orange (C. sinensis 'Madam Vinous'); 18, Hamlin sweet orange (C. sinensis 'Hamlin'); 19, Calamondin (×Citrofortunella microcarpa); 20, Severinia buxifolia; 21, Zanthoxylum fagara; 22, Murraya paniculata; 23, periwinkle (Catharanthus roseus); and 24, dodder (Cuscuta indecora). 
L. asiaticus', they were compared in this study. With increased chemical concentrations in all three replicates, PMA reached a saturated stage in which added chemical did not cause further removal of DNA, whereas EMA had no such phenomenon (Fig. 2). For samples treated with the same amount of PMA or EMA, samples treated with PMA usually had a higher DNA yield (Fig. 2). The results confirmed that EMA removes substantial DNA from live bacteria in suspension (i.e., lower selectivity of EMA compared with PMA). The final concentration of $25 \mu \mathrm{g} / \mathrm{ml}$ was chosen for PMA-qPCR detection of ' $\mathrm{Ca}$. L. asiaticus'. This concentration was considered sufficient to effectively remove genomic DNA from dead cells while avoiding potential DNA loss due to excessive dye.

TL treatment effect on GLB. PMA-qPCR was developed to estimate the GLB inside hosts. However, certain processes in the PMA protocol might have adverse effects on the integrity of the bacterial cell structures, which could render the data inaccurate and produce an underestimate of the actual live population. For example, the extremely low temperature in $\mathrm{LN}$ treatment could cause the bacterial cells to freeze and thaw. Also, no research data support the assumption that the intense pounding by metal beads would not harm the bacterium inside the tissues. In long-term storage using $\mathrm{LN}$, bacteria experience extreme temperature changes but still remain viable. However, long-term storage is done with pure bacterial cultures and uses glycerol to protect the membrane from freeze damage. Therefore, investigation into this matter was necessary.

The TL treatment in the PMA pretreatment not only had no significant impact on the GLB inside plant tissue but also tended to increase the estimate of the TGP. In addition, the LN treatment alone had no significant impact on either GLB or TGP. However the pounding with steel beads seemed to have an adverse effect on GLB (i.e., fewer live bacteria detected) but not on the TGP.

The smallest variations of GLB detected in the samples "With LN + PD" demonstrated the reliability of PMA-qPCR in fulfilling its purpose. In addition, the large variations of TGP in all four groups including "With LN + PD" implied that TGP is not suitable to be used for monitoring the dynamic change of the bacterial population in HLB research.

Plant tissue interference with PMA-qPCR. PMA-qPCR has been repeatedly reported to work well with culturable pathogenic bacteria $(20,23,31,42)$, but there is no report of PMA-qPCR application on uncultured bacteria such as ' $\mathrm{Ca}$. L. asiaticus'. In order to demonstrate the effectiveness of the optimized PMA-qPCR proto- col with plant tissue, the experiment with the mixture of plant tissue and bacterial suspensions of defined live/dead cell ratios was used to mimic the situation in ' $\mathrm{Ca}$. L. asiaticus'-infected plant samples. Half of the bacterial suspension from a fresh culture of $\log$ phase of $X$. citri subsp. citri was subject to exposure to $70 \%$ isopropanol for $10 \mathrm{~min}$, resulting in a decrease in culturable bacterial cells to zero. With the increase of dead cells in the mixed bacterial suspension, the GLB detected by qPCR after PMA treatment decreased as expected, and the "DNA yield in percent" data agreed well with the defined live/dead bacterial ratios. This showed that PMA-qPCR was not interfered with by plant tissue.

PMA-qPCR versus bacterial rods/field. With an effective and reliable PMA-qPCR protocol and proper experimental material (i.e., alimentary canals dissected from psyllids), a linear relationship between microscopically observable Liberibacter rods and quantitative PCR results was established in this work. With this standard curve, the live ' $\mathrm{Ca}$. L. asiaticus' population inside hosts (plants or psyllid) can be estimated with data obtained from either of the two methodologies. Because microscopic observation of ' $\mathrm{Ca}$. L. asiaticus' only counts cells with rod-shaped cell structure, while regular qPCR (without PMA pretreatment) detects the whole bacterial genome no matter from live or dead cells, there is always a considerable discrepancy between the genome estimates made by these two methodologies $(21,39)$. PMA can effectively remove background DNA (DNA from dead cells and naked DNA molecules) from the TGP and make only DNA of live cells detectable in subsequent qPCR assays. Therefore, this additional treatment made qPCR results theoretically comparable with what you could actually see under a microscope and, thus, a possible correlation standard curve.

When converting qPCR results to actual bacterial genomes, standard curves developed with the PCR target on a recombinant plasmid are a common option $(21,39,41)$. However, such standard curves were problematic when used for field samples in HLB research, and optimizations for them were constantly being made; for example, a major modification was made for standard curves so that the factors of host tissue, host species, and even geographic locations could be taken into account (22). In another study, the host tissue was proven to be an insignificant factor in the development of standard curve for the quantification of ' $\mathrm{Ca}$. L. asiaticus' (39). The difference in performance of recombinant plasmid and bacterial genomic DNA in qPCR assays remained unstudied. Therefore, we used the microscopic counting of live ' $\mathrm{Ca}$. L. asiaticus' to develop our standard curve.

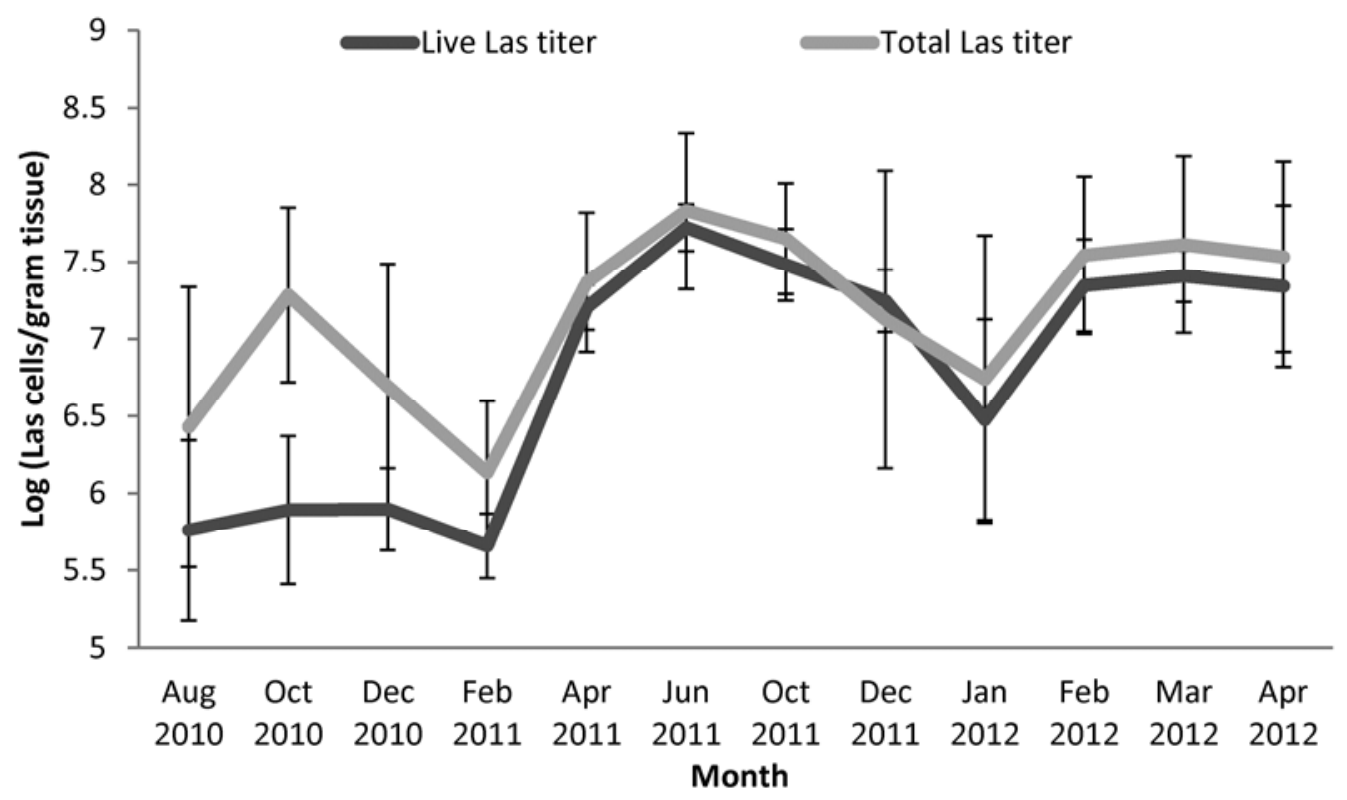

Fig. 8. Dynamics of the genomes from live and total 'Candidatus Liberibacter asiaticus' (Las) in 'Valencia' sweet orange over a 20-month period. After being inoculated with psyllids in November 2009 , three 'Ca. L. asiaticus'-positive Valencia seedlings were monitored monthly by propidium monoazide quantitative polymerase chain reaction for live bacterial dynamics. Populations were mean values and the error bars represented standard deviations from the three plants. 
When counting ' $\mathrm{Ca}$. L. asiaticus' from psyllids under a microscope, there was a general impression that live bacteria were more prevalent than dead ones in psyllids (Fig. 5A versus B); however, the live bacterial percentage in psyllids obtained by PMA-qPCR (20 to $40 \%$ ) was lower than the observation. This discrepancy could be due to the disrupted bacterial cells which could not be seen with either dye under the microscope but was still detectable in qPCR (28).

GLB in different hosts. According to the results shown in Figure 7, different citrus species and cultivars were able to accumulate high levels of live ' $\mathrm{Ca}$. L. asiaticus' genome regardless of their susceptibility to HLB. In general, no significant difference in the GLB was observed between a susceptible citrus species (or cultivar) and a more resistant one. This suggests that there is no strong correlation between citrus susceptibility to HLB and the internal bacterial populations. S. buxifolia and Calamondin $(\times$ Citrofortunella microcarpa) showed no difference with Citrus spp. as hosts of 'Ca. L. asiaticus', whereas M. paniculata and Z. fagara had significantly lower ' $C a$. L. asiaticus' genome compared with citrus. This means that ' $\mathrm{Ca}$. L. asiaticus' could not accumulate to a high level in these two plants, and may further indicate an unsuitable living environment inside these two plants for the bacterium. The ' $\mathrm{Ca}$. L. asiaticus' genome was significantly higher in dodder than in citrus, which helps to explain why dodder serves as an excellent host and transmission vector for ' $\mathrm{Ca}$. L. asiaticus'.

GLB dynamics in 'C $\boldsymbol{C}$. $\mathrm{L}$. asiaticus'-infected sweet orange. Factors such as the initial inoculum, plant age, bacteria growth phase, environmental conditions (such as light, temperature, and water), and plant nutrition could affect ' $\mathrm{Ca}$. L. asiaticus' growth and, thus, contribute to the ' $\mathrm{Ca}$. L. asiaticus' population dynamics inside plant hosts. However, in this greenhouse study with controlled conditions, many factors could be eliminated when analyzing the two-staged ' $\mathrm{Ca}$. L. asiaticus' growth pattern observed. Considering that the sudden rise of GLB happened between February and April, when the plants just finished the dormant period in winter, and ' $\mathrm{Ca}$. L. asiaticus' is an intracellular bacterium (9), the twostaged pattern could be a seasonal growth pattern along with the plant growth. However, before identifying the real reason behind the change, the information revealed in this development pattern (or growth curve) could be useful in HLB management. For example, if a pesticide application is needed twice a year for HLB treatment, knowing that a bacterial population outbreak would occur in April could indicate that psyllid control is needed before the bacterial population increases.

The live bacterial percentage varied considerably in this study (from less than 1 to almost $100 \%$ ). It is difficult to conclude any host-pathogen interaction due to the low number of bacteria that are visualized in affected plant tissues. Phloem plugging and necrosis is present in most HLB-affected citrus tissues and sometimes degraded bacteria are seen (11). However, live bacteria are found in young growing tissues (11) and are acquired and transmitted by psyllid vectors.

The TGP detected by regular qPCR is the sum of live bacteria, dead bacteria (with integrity-compromised cell structure), and naked DNA of the target organism in the sample. The detection of the TGP may fulfill some diagnostic purpose but the data are less informative due to their mixed nature. With this optimized PMAqPCR methodology, the more informative genomes from live bacteria inside ' $\mathrm{Ca}$. L. asiaticus'-infected hosts can now be determined and, thus, assist in HLB research and disease management.

\section{Literature Cited}

1. Alvarez, A. M. 2004. Integrated approaches for detection of plant pathogenic bacteria and diagnosis of bacterial diseases. Annu. Rev. Phytopathol. 42:339-366.

2. Bach, H. J., Tomanova, J., Schloter, M., and Munch, J. C. 2002. Enumeration of total bacteria and bacteria with genes for proteolytic activity in pure cultures and in environmental samples by quantitative PCR mediated amplification. J. Microbiol. Methods 49:235-245.

3. Bove, J. M. 2006. Huanglongbing: a destructive, newly-emerging, centuryold disease of citrus. J. Plant Pathol. 88:7-37.
4. Cawthorn, D. M., and Witthuhn, R. C. 2008. Selective PCR detection of live Enterobacter sakazakii cells utilizing propidium monoazide or ethidium bromide monoazide. J. Appl. Microbiol. 105:1178-1185.

5. Contreras, P. J., Urrutia, H., Sossa, K., and Nocker, A. 2011. Effect of PCR amplicon length on suppressing signals from membrane-compromised cells by propidium monoazide treatment. J. Microbiol. Methods 87:89-95.

6. Cubero, J., and Graham, J. H. 2002. Genetic relationship among worldwide strains of Xanthomonas causing canker in citrus species and design of new primers for their identification by PCR. Appl. Environ. Microbiol. 68:12571264.

7. Cubero, J., and Graham, J. H. 2005. Quantitative real-time polymerase chain reaction for bacterial enumeration and allelic discrimination to differentiate Xanthomonas strains on citrus. Phytopathology 95:1333-1340.

8. da Graca J. V. 1991. Citrus greening disease. Annu. Rev. Phytopathol. 29:109-136.

9. Duan, Y., Zhou, L., Hall, D. G., Li, W., Doddapaneni, H., Lin, H., Liu, L., Vahling, C. M., Gabriel, D. W., Williams, K. P., Dickerman, A., Sun, Y., and Gottwald, T. 2009. Complete genome sequence of citrus huanglongbing bacterium, 'Candidatus Liberibacter asiaticus' obtained through metagenomics. Mol. Plant-Microbe Interact. 22:1011-1020.

10. Flekna, G., Stefanic, P., Wagner, M., Smulders, F. J. M., Mozina, S. S., and Hein, I. 2007. Insufficient differentiation of live and dead Campylobacter jejuni and Listeria monocytogenes cells by ethidium monoazide (EMA) compromises EMA/real-time PCR. Res. Microbiol. 158:405-412.

11. Folimonova, S. Y., and Achor, D. S. 2010. Early events of citrus greening (Huanglongbing) disease development at the ultrastructural level. Phytopathology 100:949-958

12. Garnier, M, Eveillard, S. J., Cronje, P. R., Le Roux, H. F., and Bove, J. M. 2000. Genomic characterization of a Liberibacter present in an ornamental rutaceous tree, Calodendrum capense, in the Western Cape province of South Africa. Proposal of 'Candidatus Liberibacter africanus subsp. capensis'. Int. J. Syst. Evol. Microbiol. 50:2119-2125.

13. Halbert, S. 2005. The discovery of Huanglongbing in Florida. Page 50 in: Proc. 2nd Int. Citrus Canker Huanglongbing Workshop, Orlando, FL.

14. Halbert, S. E., and Manjunath, K. L. 2004. Asian citrus psyllids (Sternorrhycha: Psyllidae) and greening disease of citrus: a literature review and assessment of risk in Florida. Fla. Entomol. 87:330-353.

15. Hocquellet, A., Toorawa, P., Bové, J. M., and Garnier, M. 1999. Detection and identification of the two Candidatus Liberobacter species associated with citrus huanglongbing by PCR amplification of ribosomal protein genes of the $\beta$-operon. Mol. Cell. Probes 13:373-379.

16. Jagoueix, S., Bové, J. M., and Garnier, M. 1994. The phloem-limited bacterium of greening disease of citrus is a member of the alpha subdivision of the Proteobacteria. Int. J. Syst. Bacteriol. 44:379-386.

17. Jagoueix, S., Bové, J. M., and Garnier, M. 1996. PCR detection of the two 'Candidatus' Liberobacter species associated with greening disease of citrus. Mol. Cell. Probes 10:43-50.

18. Josephson, K. L., Gerba, C. P., and Pepper, I. L. 1993. Polymerase chain reaction detection of nonviable bacterial pathogens. Appl. Environ. Microbiol. 59:3513-3515.

19. Kobayashi, H., Oethinger, M., Tuohy, M. J., Hall, G. S., and Bauer, T. W. 2009. Unsuitable distinction between live and dead Staphylococcus aureus and Staphylococcus epidermidis by ethidium bromide monoazide. Lett. Appl. Microbiol. 48:633-638.

20. Kobayashi, H., Oethinger, M., Tuohy, M. J., Hall, G. S., and Bauer, T. W. 2009. Improving clinical significance of PCR: use of propidium monoazide to distinguish live from dead Staphylococcus aureus and Staphylococcus epidermidis. J. Orthopaed. Res. 27:1243-1247.

21. Li, W., Hartung, J. S., and Levy L. 2006. Quantitative real-time PCR for detection and identification of 'Candidatus Liberibacter species' associated with citrus huanglongbing. J. Microbiol. Methods 66:104-115.

22. Li, W., Li, D., Twieg, E., Hartung, J. S., and Levy, L. 2008. Optimized quantification of unculturable 'Candidatus Liberibacter spp.' in host plants using real-time PCR. Plant Dis. 92:854-861.

23. Liang, N., Dong, J., Luo, L., and Li, Y. 2011. Detection of live Salmonella in Lettuce by propidium monoazide real-time PCR. J. Food Sci. 76:M234-237.

24. Manjunath, K., Halbert, S., Ramadugu, C., Webb, S., and Lee, R. 2008. Detection of 'Candidatus Liberibacter asiaticus' in Diaphorina citri and its importance in the management of Citrus huanglongbing in Florida. Phytopathology 98:387-396.

25. Masters, C. I., Shallcross, J. A., and Mackey, B. M. 1994. Effect of stress treatments on the detection of Listeria monocytogenes and enterotoxigenic Escherichia coli by the polymerase chain reaction. J. Appl. Bacteriol. 77:73-79.

26. Mavrodieva, V., Levy, L., and Gabriel, D. W. 2004. Improved sampling methods for real-time polymerase chain reaction diagnosis of citrus canker from field samples. Phytopathology 94:61-68.

27. Nocker, A., and Camper, A. K. 2006. Selective removal of DNA from dead cells of mixed bacterial communities by use of ethidium monoazide. Appl. Environ. Microbiol. 72:1997-2004.

28. Nocker, A., and Camper, A. K. 2009. Novel approaches toward preferential detection of live cells using nucleic acid amplification techniques. FEMS Microbiol. Lett. 291:137-142.

29. Nocker, A., Cheung, C. Y., and Camper, A. K. 2006. Comparison of propid- 
ium monoazide with ethidium monoazide for differentiation of live vs. dead bacteria by selective removal of DNA from dead cells. J. Microbiol. Methods 67:310-320.

30. Nocker, A., Richter-Heitmann, T., Montijn, R., Schuren, F., and Kort, R. 2010. Discrimination between live and dead cells in bacterial communities from environmental water samples analyzed by 454 pyrosequencing. Int. Microbiol. 13:59-62.

31. Nocker, A., Sossa, K. E., and Camper, A. K. 2007. Molecular monitoring of disinfection efficacy using propidium monoazide in combination with quantitative PCR. J. Microbiol. Methods 70:252-260.

32. Nocker, A., Sossa-Fernandez, P., Burr, M. D., and Camper, A. K. 2007. Use of propidium monoazide for live/dead distinction in microbial ecology. Appl. Environ. Microbiol. 73:5111-5117.

33. Planet, P., Jagouxie, S., Bové, J. M., and Garnier, M. 1995. Detection and characterization of the African citrus greening liberobacter by amplification, cloning and sequencing of the rplKAJL-ropBC operon. Curr. Microbiol. 30:137-141.

34. Rudi, K., Moen, B., Drømtrop, S. M., and Holck, A. L. 2005. Use of ethidium monoazide and PCR in combination for quantification of live and dead cells in complex samples. Appl. Environ. Microbiol. 71:1018-1024.

35. Tatineni, S., Sagaram, U. S., Gowda, S., Robertson, C. J., Dawson, W. O., Iwanami, T., and Wang, N. 2008. In planta distribution of 'Candidatus Liberibacter asiaticus' as revealed by polymerase chain reaction (PCR) and real-time PCR. Phytopathology 98:592-599.

36. Teixeira, D. A., Eveillard, S., Martins, E. C., Jesus, W. C., Jr., Yamamoto, P. T., Lopes, S. A., Bassanezi, R. B., Ayres, A. J., Saillard, C., and Bové, J. M.
2005. Citrus huanglongbing in São Paulo State, Brazil: PCR detection of the 'Candidatus Liberibacter species' associated with the disease. Mol. Cell. Probes 19:173-179.

37. Teixeira, D. A., Saillard, C., Eveillard, S., Danet, J. L., da Costa, P. I., Ayres, A. J., and Bové, J. M. 2005. 'Candidatus Liberibacter americanus' associated with citrus huanglongbing (greening disease) in São Paulo State, Brazil. Int. J. Syst. Evol. Microbiol. 55:1857-1862.

38. Teixeira, D. A., Wulff, N., Martins, E., Kitajima, E., Bassanezi, R., Ayres, A., Eveillard, S., Saillard, C., and Bove, J. 2008. A phytoplasma closely related to the pigeon pea witches'-broom phytoplasma (16Sr IX) is associated with citrus huanglongbing symptoms in the state of Sao Paulo, Brazil. Phytopathology 98:977-98.

39. Trivedi, P., Sagaram, U. S., Kim, J. S., Brlansky, R. H., Rogers, M. E., Stelinski, L. L., Oswalt, C., and Wang, N. 2009. Quantification of live 'Candidatus Liberibacter asiaticus' in hosts using quantitative PCR with the aid of ethidium monoazide (EMA). Eur. J. Plant Pathol. 124:553-563.

40. Wang, S., and Levin, R. E. 2006. Discrimination of live Vibrio vulnificus cells from dead cells in real-time PCR. J. Microbiol. Methods 64:1-8.

41. Wang, Z., Yin, Y., Hu, H., Yuan, Q., Peng, G., and Xia, Y. 2006. Development and application of molecular-based diagnosis for 'Candidatus Liberibacter asiaticus', the causal pathogen of citrus huanglongbing. Plant Pathol. 55:630-638.

42. Yanez, M. A., Nocker, A., Soria-Soria, E., Murtula, R., Martinez, L., and Catalan, V. 2011. Quantification of live Legionella pneumophila cells using propidium monoazide combined with quantitative PCR. J. Microbiol. Methods 85:124-130. 